9. Иванов В. П. Трехмерная компьютерная графика / В. П. Иванов, А. С. Батраков ; под ред. Г. М. Полищука. - М. : Радио и связь, 1995. - 224 с.

10. Когут Л. В. Тривимірна графіка. URL: http://edufuture.biz/index.php?title (дата звернення: 9.10.2019)

11. Козяр М. М. Сучасні програмні засоби проектування та геометричного моделювання : навч. посіб. / М. М. Козяр. - Рівне : МОНУ, НУВГП, 2006. 298 c.

12. Комп'ютерна анімація // Вікіпедія. URL: https://uk.wikipedia.org (дата звернення: 9.10.2019).

13. Новые педагогические и информационные технологии в системе образования : учеб. пособие для студ. пед. вузов и системы повыш. квалиф. пед. кадров / Е. С. Полат, М. Ю. Бухаркина, М. В. Моисеева, А. Е. Петров ; под ред. Е. С. Полат. - М. : Издательский центр «Академия», 2001. - 272 с.

14. Перспективи розвитку 3D-графіки. URL: http://nadoest.com/perspektivi-3d-grafiki (дата звернення: 9.10.2019).
15. Пугачев В. М. Роль информационных технологий в науке и образовании / В. М. Пугачев, Е. Г. Газенаур // Вестник КемГУ. - 2009. - № 3. C. 31-34.

16. Рукавишников В. А. Проблемы геометрического моделирования в автоматизированном проектировании и производстве : сб. статей I Междунар. науч. конф. / В. А. Рукавишников. - М. : МГИУ, 2008. - С. 316-319.

17. Рукавишников В. А. Новый уровень в развитии графического образования / В. А. Рукавишников, И. Л. Голубева, А. Р. Альтапов // Третьи Вавиловские чтения : материалы Всеросс. междисцип. науч. конф.Йошкар-Ола, 1999. - Ч. 1. - С. 200-202.

18. Час і простір - Концепції сучасного природознавства. URL: https://westudents.com.ua/glavy/7473923-chas-prostr.html (дата звернення: 13.10.2019).

19. Quick Overview of 4D Graphics - Motion Controls Robotics. URL: https://motioncontrolsrobotics.com/quickoverview-4d-graphics/ (дата звернення: 13.10.2019).

Дата надходження до редакиіï: 21.10.2019 р.

Валентина КОРОЛЬЧУК,

асистентка кафедри інформаційних

і дистаниійних технологій

Національного університету біоресурсів

і природокористування України, м. Київ

\title{
ХМАРНІ СЕРВІСИ ДЛЯ ВИКОНАННЯ КОЛЕКТИВНИХ ПРОЕКТІВ У ПРОЦЕСІ ПІДГОТОВКИ МАЙБУТНІХ ІТ-ФАХІВЦІВ: АНАЛІЗ ТА КРИТЕРІЇ ДОБОРУ
}

У статті проаналізовано критеріі добору хмарних сервісів для управління проєктами та колективної розробки програмних продуктів, використання яких буде доцільним у прочесі підготовки майбутніх фахівиів з інформаиійних технологій. Наведено порівняльну характеристику відібраних хмарних сервісів за визначеними критеріями та показниками, а також запропоновано рекомендації щзодо їх використання у прочесі організаиії проєктної роботи й розробки програмних продуктів. Представлено результати педагогічного дослідження щодо використання означених хмарних сервісів у процесі підготовки майбутніх IT-фахівиів.

Ключові слова: колективні проєкти, майбутні фахівці з інформаційних технологій, хмарні сервіси для управління проєктами, хмарні сервіси для колективної розробки програмних продуктів, критерії добору.
В статье проанализированы критерии отбора облачных сервисов для управления проектами и коллективной разработки программных продуктов, использование которых будет ичелесообразным в проиессе подготовки будущих специалистов по информационным технологиям. Приведена сравнительная характеристика отобранных облачных сервисов по определенным критериям и показателям, а также предложень рекомендации по их использованию в процессе организачии проектной работы и разработки программных продуктов. Представлены результаты педагогического исследования по использованию указанных облачных сервисов в процессе подготовки будущчих ИТ-специалистов.

Ключевые слова: коллективные проекты, будущие специалисты по информачионным технологиям, облачные сервисы для управления проектами, облачные сервисы для разработки программных продуктов, критерии добора. 
The criteria for selecting cloud services for project management (ability to form groups, assign tasks to team members, prioritize tasks, communicate between team members, organize video calls, organize real-time collaboration, plan and save team work results, embed additional services) and collective development of software products (ability to collaborate on code, bug tracking, discuss code with other team members, manage code versions and integrate additional services, have a repository, wiki, and code editor) that should be used in the preparation of future IT professionals are analyzed and outlined in the paper. A comparative description of selected cloud services according to certain criteria and indicators are presented in this study. The recommendations on the use of appropriate services for the organization of project work (Microsoft Teams, Asana, Trello, Jira) and collective development of software products (GitHub, Bitbucket, DeployBot, Phabricator, Beanstalk) are offered by the author. The pedagogical research involves 42 expert-students of the Computer Science speciality. The results of the use of certain cloud services for project management and collective development of software products in the study of professional disciplines are presented. According to the pedagogical research, the most effective cloud services for project management and collective development of software products in the process of training future IT specialists according to certain criteria are Jira and GitHub cloud services, respectively. Examples and results of using certain cloud services in the process of training future IT professionals are given.

Key words: team projects, future professionals in information technologies, cloud services for project management, cloud services for collective software development, selection criteria.

Постановка проблеми. Із розвитком інформаційних технологій (далі - IT) змінюється і підхід до організації колективної розробки програмних продуктів. У зв'язку з цим необхідно враховувати той факт, що майбутні IT-фахівці повинні вміти швидко адаптуватися до нових ситуацій, вирішувати поставлені завдання не лише особисто, а й під час роботи в команді, а також приймати відповідні рішення. Для того, щоб студенти IT-фаху у своїй діяльності могли займати провідні позиції у сфері IT, відповідати вимогам замовників і роботодавців, необхідно ще під час навчання в університеті розвивати в них уміння розробляти й управляти проєктами, працювати в команді, використовувати хмарні сервіси для управління проєктами та колективної розробки програмних продуктів.

Аналіз наукових досліджень та публікацій. Проблему підготовки майбутніх фахівців 3 інформаційних технологій у закладах вищої освіти (далі - 3ВО) у своїх дослідженнях висвітлювали О. Глазунова [3], Л. Зубик [7], В. Концедайло [5], В. Круглик, С. Симоненко [7], С. Литвинова, С. Проскура [9], В. Осадчий [7, 8], К. Осадча [8] та ін.

А. Власюк і П. Грицюк [1] зауважують, що основною особливістю роботи інженера-програміста $€$ перехід від проєкту до проєкту, необхідність постійно переключати увагу, а основними професійними якостями - швидке опанування певної предметної галузі, вміння самостійно ухвалювати рішення, швидко адаптуватися до нових умов тощо.
На сьогодні існує значна кількість хмарних сервісів для колективної проєктної роботи, наприклад: Trello, Microsoft Teams, Asana, GitHub, Bitbucked, GitLab та інші. Вони дозволяють забезпечити взаємодію учасників освітнього процесу (управління проєктами та завданнями, колективну розробку програмних продуктів), а також можуть бути використані на різних етапах організації аудиторного заняття чи в ході самостійної роботи студентів [2; 6; 13$]$.

В. Татауров і К. Чевська [11] у своїй праці розкривають можливості хмарного сервісу Microsoft Teams під час організації навчального процесу студентів IT-фаху, розглядають його інтеграцію з іншими сервісами Microsoft Office 365. А. Елісон та М. Арора [12], а також О. Глазунова, О. Кузьмінська, Т. Волошина, Т. Саяпіна, В. Корольчук [14] описують досвід використання хмарних сервісів Microsoft Office 365 для організації групової проєктної роботи, зокрема акцентують увагу на залученні студентів до проєктування порталів на базі Microsoft SharePoint.

Дж. Феліціано, М. Сторі, О. Загальський (J. Feliciano, M. Storey, A. Zagalsky) [13] надають рекомендації стосовно того, як можна використовувати такі хмарні сервіси, як GitHub при підготовці фахівців з інженерії програмного забезпечення, а також як викладачам ефективніше інтегрувати означені сервіси у свої навчальні курси.

Для організації роботи команди на всіх етапах виконання проєкту, починаючи від планування та розподілу завдань і закінчуючи презентацією готового продукту, доцільно використовувати хмарні сервіси для управління проєктами, а для виконання самих завдань проєкту - різноманітні фахово орієнтовані засоби, зокрема хмарні сервіси для колективної розробки програмних продуктів.

Мета статті - проаналізувати та визначити найбільш ефективні хмарні сервіси для організації колективної проєктної роботи студентів IT-фаху.

Виклад основного матеріалу. У сучасних умовах IT-індустрії важливо розвивати в студентів IT-фаху вміння колективно розробляти програмні продукти, знання та розуміння етапів такої розробки, а також планування означеної діяльності та формування вмінь і навичок роботи над колективним проєктом. Ураховуючи динаміку змін у сфері IT та потреби з боку замовників, IT-фахівцеві необхідно вміти швидко мінімізувати ризики та адаптуватися до мінливих ситуацій, що виникають у процесі роботи. Для оволодіння такими навичками студентів IT-фаху необхідно знайомити з гнучкими методологіями розробки програмних продуктів та відповідними хмарними сервісами, які сприятимуть реалізації означеної методології у процесі роботи над колективними проєктами. Саме такі методології об’єднують одним терміном - «agile-методи». Agile розуміють як використання під час проєкту гнучких підходів, наприклад, таких, як Scrum, Kanban, Extreme Programming тощо, в яких вимоги до продукту та рішення розвиваються на основі співпраці всіх учасників команди. Це сприяє швидкому плануванню завдань проєкту та їх виконанню, випуску продукту та постійному його вдосконаленню, дозволяє миттєво та гнучко реагувати на необхідні зміни. Для організації роботи команд над розробкою програмних продуктів, необхідно оволодіти діяльністю саме 3 хмарними сервісами, 
які дають змогу якісно організувати взаємодію команди та забезпечити спільну розробку програмних продуктів. Використання даних методологій під час виконання навчальних проєктів сприяє розвитку в студентів IT-фаху не лише професійних навичок, а й особистісних.

Ураховуючи швидкість змін у сфері IT, постійно зростає кількість хмарних сервісів для командної роботи, однак, оцінюючи функціонал таких сервісів, їх можна розподілити на дві категорії: 1) хмарні сервіси для управління проєктами; 2) хмарні сервіси для колективної розробки програмного продукту.

Хмарні сервіси для управління проєктами допомагають відслідковувати роботу учасників команди, розподіляти завдання між ними, визначати їхню пріоритетність тощо. До цієї категорії сервісів відносять Microsoft Teams, Asana, Trello, Jira та інші (див. табл. 1).

Порівняльна характеристика хмарних сервісів для управління проектами

\begin{tabular}{|c|c|c|c|c|}
\hline Критерії & Microsoft Teams & Asana & Trello & Jira \\
\hline Можливість формування груп & канал & $\begin{array}{c}\text { команда, } \\
\text { проєкт }\end{array}$ & $\begin{array}{c}\text { команда, } \\
\text { бізес-команда, } \\
\text { дошка }\end{array}$ & проєкти \\
\hline $\begin{array}{c}\text { Можливість постановки завдань } \\
\text { учасникам команди }\end{array}$ & завдання & завдання & картка & завдання \\
\hline Можливість пріоритезації задач & - & - & - & + \\
\hline $\begin{array}{c}\text { Можливість комунікації } \\
\text { між учасниками команди }\end{array}$ & Chat, Skype, Yammer & $\begin{array}{c}\text { коментарі, } \\
\text { обговорення }\end{array}$ & коментарі & коментарі \\
\hline Можливість організації відеозв'язку & + & - & - & - \\
\hline $\begin{array}{c}\text { Можливість організації спільної } \\
\text { роботи в реальному часі }\end{array}$ & $\begin{array}{c}\text { Word, Excel, } \\
\text { PowerPoint, OneNote, } \\
\text { SharePoint, Power BI }\end{array}$ & - & - & - \\
\hline Можливість зберігання файлів & OneDrive & файли проєкту & вкладення & вкладення \\
\hline $\begin{array}{c}\text { Можливість планування } \\
\text { спільної роботи }\end{array}$ & $\begin{array}{c}\text { дошка } \\
\text { (Dashboard), } \\
\text { календар }\end{array}$ & $\begin{array}{c}\text { дошкандар } \\
\text { (Dashboard) }\end{array}$ & $\begin{array}{c}\text { дошка } \\
\text { (Dashboard) }\end{array}$ \\
\hline $\begin{array}{c}\text { Можливість вбудування } \\
\text { додаткових сервісів }\end{array}$ & + & + & + & + \\
\hline
\end{tabular}

Хмарні сервіси для колективної розробки програмних продуктів дають змогу користувачам спільно працювати над кодом, керувати версіями тощо. До таких сервісів відносять: GitHub, Bitbucked, GitLab, Phabricator, Beanstalk та iн.

Обираючи хмарні сервіси для управління проєктами, необхідно врахувати можливість формування груп, постановки завдань учасникам команди, пріоритезації задач, комунікації між учасниками команди, організації відеозв'язку та організації спільної роботи в реальному часі, планування та збереження результатів командної роботи, вбудовування додаткових сервісів.

Одним із важливих різновидів проєктів у ході підготовки IT-фахівців $є$ проєкти 3 колективної розробки програмних продуктів, саме тому ще зі студентської лави важливо готувати студентів до виконання таких проєктів, розвивати в них необхідні для цього професійні та особистісні навички. Обираючи хмарні сервіси для колективної розробки програмних продуктів, необхідно звертати увагу на можливість спільної роботи над кодом, відстеження помилок, обговорення коду з іншими учасниками команди, управління версіями коду та інтеграції додаткових сервісів, наявність репозиторію, вікі та редактора коду тощо. Для того, щоб хмарні сервіси колективної розробки програмних продуктів допомагали керувати проєктами, в них необхідно інтегрувати додаткові сервіси. Саме тому можливість такої інтеграції $\epsilon$ одним з основних критеріїв, за яким здійснюється порівняльна характеристика хмарних сервісів для колективної розробки програмних продуктів (див. табл. 2).

Поєднання між собою хмарних сервісів із двох вищеозначених категорій у ході роботи над проєктом дає можливість студентам IT-фаху ще під час навчання у ЗВО повною мірою відтворити процес розробки програмних продуктів та виявити особливості роботи 3 кожним із сервісів.

Ю. Слюсарчук уважає, що реалізація проєктно зорієнтованого навчання дає змогу сформувати у студентів уміння розробляти та керувати проєктами, планувати час, продукувати нові ідеї, здійснювати пошук та аналіз інформації з різних джерел, працювати в команді, оцінювати та підтримувати якість виконаної роботи [10].

Як приклад, розглянемо колективний проєкт, який організували студенти III курсу спеціальності 122 «Комп'ютерні науки» на базі Національного університету біоресурсів і природокористування України. Метою організації даного проєкту було формування в майбутніх фахівцівзінформаційних технологій інтегральноїкомпетентності, розвиток їх професійних та особистісних навичок.

Студентам IT-фаху було запропоновано виконання міждисциплінарного проєкту на тему «Аналіз та розробка веборієнтованої системи для компанії в IT-галузі». Перед студентами було поставлено завдання: розробити проєкт для відкриття власного IT-бізнесу, що передбачає проведення аналізу ринку IT-послуг; здійснення структурно-функціонального та об'єктно орієнтованого аналізу предметної галузі; проєктування бази даних та функціоналу системи; створення веборієнтованої системи для функціонування IT-компанії; розробка бізнес-плану зі створення IT-компанії та стратегій іiі розвитку; розрахунок окупності проєкту. 


\section{Порівняльна характеристика хмарних сервісів для колективної розробки програмних продуктів}

\begin{tabular}{|c|c|c|c|c|c|}
\hline Критерій & GitHub & Bitbucket & DeployBot & \begin{tabular}{|l|} 
Phabricator \\
\end{tabular} & Beanstalk \\
\hline $\begin{array}{c}\text { Можливість спільної } \\
\text { роботи над кодом }\end{array}$ & + & + & + & + & + \\
\hline $\begin{array}{c}\text { Можливість відстеження } \\
\text { помилок }\end{array}$ & + & + & - & + & - \\
\hline $\begin{array}{c}\text { Наявність стрічки } \\
\text { активності } \\
\end{array}$ & - & + & - & + & + \\
\hline Наявність репозиторію & + & + & - & + & + \\
\hline $\begin{array}{c}\text { Можливість управління } \\
\text { версіями коду }\end{array}$ & + & + & + & - & + \\
\hline Наявність редактора коду & + & + & + & + & + \\
\hline $\begin{array}{l}\text { Можливість обговорення } \\
\text { коду }\end{array}$ & + & - & - & + & - \\
\hline Наявність вікі & + & + & + & + & + \\
\hline $\begin{array}{c}\text { Можливість інтеграції } \\
\text { додаткових сервісів }\end{array}$ & Slack, Jira & $\begin{array}{c}\text { Google Analitiks, } \\
\text { Basecamp, } \\
\text { Jira } \\
\end{array}$ & \begin{tabular}{|c|} 
Slack, GitHub, \\
Bitbucked, \\
NewRelic \\
\end{tabular} & - & $\begin{array}{c}\text { Zendesk, Jira, } \\
\text { Basecamp, } \\
\text { Freekle }\end{array}$ \\
\hline $\begin{array}{l}\text { Підтримка } \\
\text { платформи }\end{array}$ & $\begin{array}{c}\text { Windows, Mac, } \\
\text { вебдодаток }\end{array}$ & вебдодаток & вебдодаток & вебдодаток & вебдодаток \\
\hline
\end{tabular}

У процесі роботи над проєктом студентам необхідно було не лише виконати поставлені перед ними задачі, а й організувати роботу команди, розподілити завдання між усіма іï учасниками, забезпечити спільну діяльність та постійно відслідковувати результати виконання кожного етапу роботи. Із цією метою студентами були використані хмарні сервіси, представлені нами в таблиці 1 .

Після виконання завдань проєкту студентам було запропоновано оцінити зручність використання кожного
3 хмарних сервісів для управління проєктами за десятибальною шкалою, враховуючи при цьому такі критерії: зручність формування груп; зручність постановки задач учасникам команди; можливість та зручність пріоритезації задач; зручність комунікації; можливість здійснення відеозв'язку; зручність колективної роботи; можливість зберігання файлів; зручність планування; можливість вбудовування додаткових сервісів. Із відповідями пропонуємо ознайомитися в таблиці 3 .

Таблиия 3

\section{Зведена таблиця узагальнених результатів оцінювання хмарних сервісів для управління просктами}

\begin{tabular}{|l|c|c|c|c|}
\hline \multicolumn{1}{|c|}{ Критерії } & $\begin{array}{c}\text { Microsoft } \\
\text { Teams }\end{array}$ & Asana & Trello & Jira \\
\hline Зручність формування груп & 8,47 & 8,64 & 8,73 & 9,22 \\
\hline Зручність постановки задач учасникам команди & 7,83 & 8,24 & 8,17 & 8,35 \\
\hline Можливість та зручність пріоритезації задач & 0 & 0 & 0 & 8,1 \\
\hline Зручність комунікації & 8,43 & 7,96 & 6,83 & 7,04 \\
\hline Можливість здійснення відеозв'язку & 5,21 & 0 & 0 & 0 \\
\hline Зручність колективної роботи & 7,44 & 7,21 & 7,04 & 7,56 \\
\hline Можливість зберігання файлів & 7,35 & 7,17 & 7,14 & 7,24 \\
\hline Зручність планування & 8,09 & 7,91 & 7,93 & 8,38 \\
\hline Можливість вбудування додаткових сервісів & 7,37 & 6,23 & 6,45 & 7,86 \\
\hline Середня оцінка & $\mathbf{6 , 6 9}$ & $\mathbf{5 , 9 3}$ & $\mathbf{5 , 8 1}$ & $\mathbf{7 , 0 8}$ \\
\hline
\end{tabular}

Таким чином, три критерії мають вагомі показники (середній бал більший за 8,0), а саме: зручність формування груп, постановки задач учасникам команди та планування. Загалом хмарний сервіс Jira був визначений студентами як найбільш ефективний для управління командою (7,08 бали). Приклад використання хмарного сервісу Jira представлено на рисунку 1 .

Виконуючи проєкти 3 розробки програмних продуктів, студентам недостатньо використовувати лише хмарні сервіси для організації роботи команди, майбутнім ІТ-фахівцям необхідні й інші сервіси, зокрема ті, що дозволять спільно працювати над кодом продукту, який планується для розробки. Після роботи з такими хмарними сервісами студентам було запропоновано оцінити їх за десятибальною шкалою за такими критеріями: зручність колективної роботи над кодом програми; зручність відслідковування помилок; наявність стрічки активності; наявність та зручність репозиторію та вікі; зручність управління версіями коду; зручність редактора коду та можливість його обговорення з іншими учасниками команди; можливість інтеграції додаткових сервісів.

Узагальнені результати оцінки хмарних сервісів для колективної розробки програмних продуктів представлено в таблиц̧i 4. 

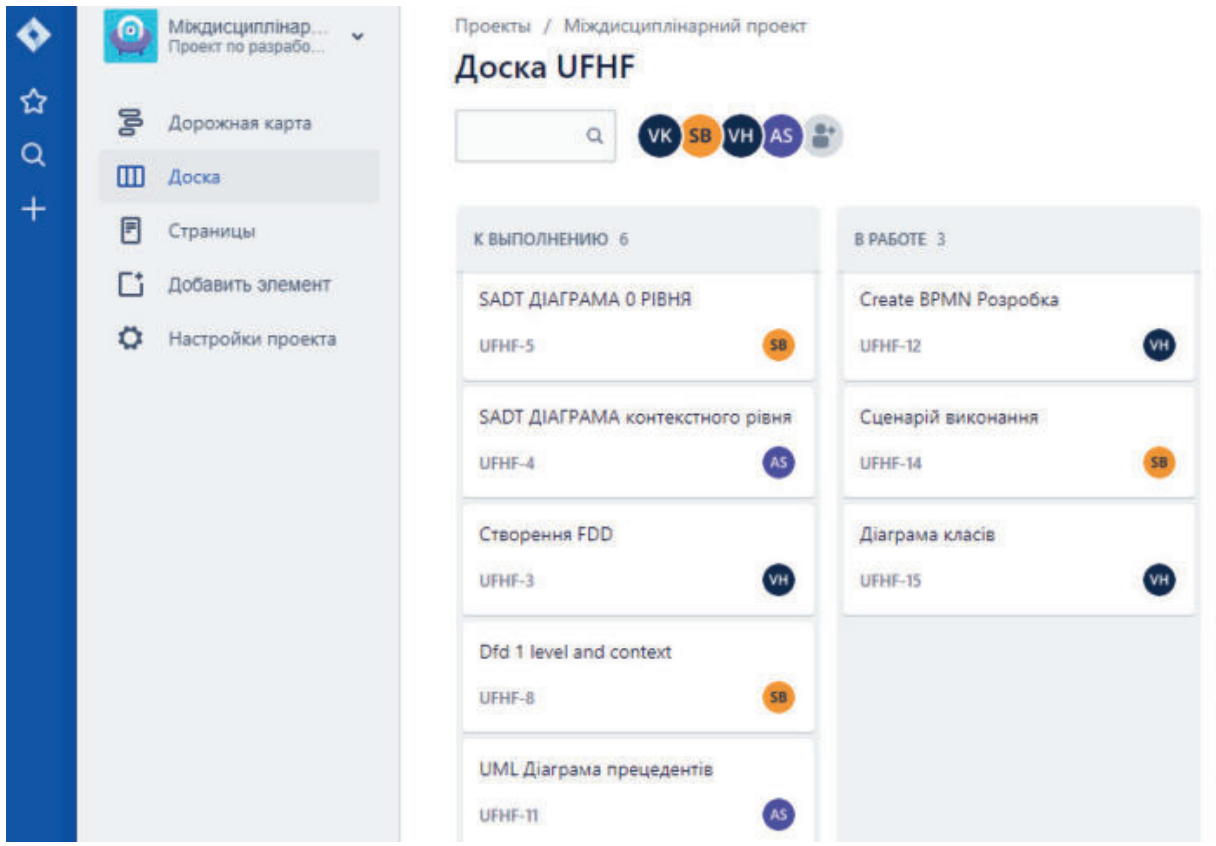

Рис. 1. Приклад організаџії колективного проєкту в хмарному сервісі Jira

Таблиця 4

Зведена таблиця узагальнених результатів оцінювання хмарних сервісів для колективної розробки програмних продуктів

\begin{tabular}{|c|c|c|c|c|c|}
\hline Критерій & GitHub & Bitbucket & DeployBot & Phabricator & Beanstalk \\
\hline $\begin{array}{l}\text { Зручність колективної роботи над кодом } \\
\text { програми }\end{array}$ & 8,62 & 7,38 & 8,13 & 7,87 & 8,06 \\
\hline Зручність відслідковування помилок & 8,73 & 8,01 & 0 & 8,32 & 0 \\
\hline Наявність стрічки активності & 0 & 6,57 & 0 & 7,29 & 7,61 \\
\hline Наявність та зручність репозиторію та вікі & 8,74 & 7,22 & 4,03 & 7,61 & 7,54 \\
\hline Зручність управління версіями коду & 8,39 & 7,62 & 7,84 & 0 & 7,95 \\
\hline $\begin{array}{l}\text { Зручність редактора коду та можливість його } \\
\text { обговорення з іншими учасниками командии }\end{array}$ & 8,67 & 7,06 & 7,76 & 8,39 & 7,14 \\
\hline Можливість інтеграції додаткових сервісів & 8,76 & 7,31 & 8,52 & 0 & 8,01 \\
\hline Середня оцінка & 7,42 & 7,31 & 5,18 & 5,64 & 6,62 \\
\hline
\end{tabular}

Deow-3/meow-3.github.io

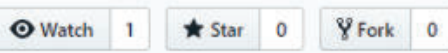

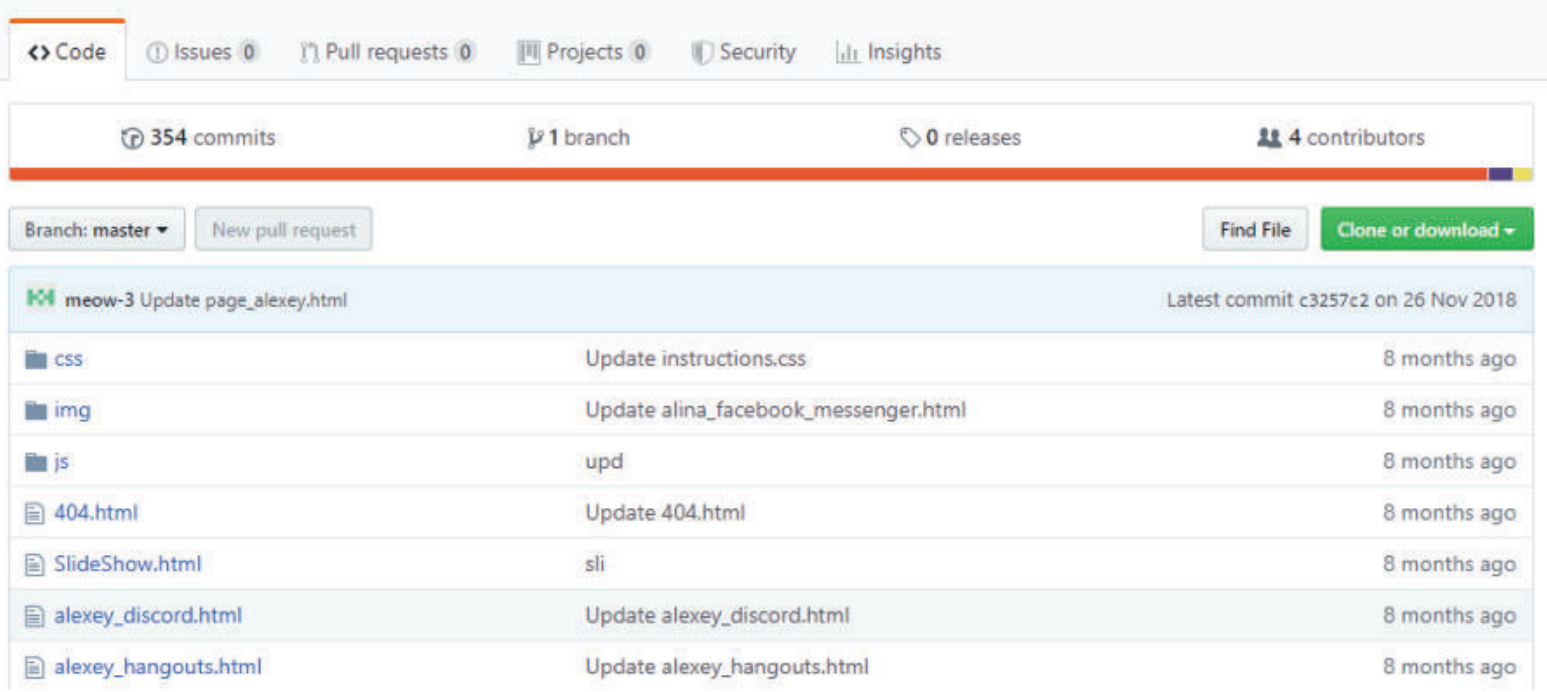

Pис. 2. Приклад використання хмарного сервісу GitHиb для колективної розробки програмного продукту 
Як видно $з$ таблиці 4, найвагомішими критеріями, на думку студентів, $є$ зручність колективної роботи над кодом програми, а також зручність редактора коду та можливість його обговорення 3 іншими учасниками команди (середній бал вищий за 7,8). Серед представлених хмарних сервісів для колективної розробки програмних продуктів найбільш ефективним студенти визначили хмарний сервіс GitHub. Приклад використання студентами хмарного сервісу GitHub для колективної розробки програмного продукту представлено на рисунку 2.

За результатами проведеного дослідження можемо стверджувати, що найбільш ефективними хмарними сервісами для управління проєктами та колективної розробки програмних продуктів у процесі підготовки студентів IT-фаху за проявом визначених критеріїв $є$ сервіси Jira та GitHub.

Висновки. На підставі представленого педагогічного дослідження нами було виявлено критерії, яких варто дотримуватися у процесі добору хмарних сервісів для управління навчальними IT-проєктами в ході підготовки майбутніх фахівців з інформаційних технологій. Зокрема, експериментальним шляхом доведено та обгрунтовано ефективність використання хмарного сервісу Jira, оскільки саме робота з ним дає можливість розвивати як професійні, так і особистісні навички студентів IT-фаху в ході виконання групових проєктів із розробки програмних продуктів та будь-яких інших IT-рішень.

Іншим хмарним сервісом, що дозволяє організувати спільну роботу над програмним кодом та контроль версій розроблюваного програмного продукту, $€$ GitHub. Саме його варто використовувати в ході навчальних проєктів. У результаті педагогічного експерименту було визначено, що даний хмарний сервіс на 22,4 \% ефективніший, порівняно з іншими, саме для колективної розробки програмного продукту майбутніми фахівцями з інформаційних технологій.

Перспективним напрямом для подальших досліджень вважаємо розробку методики використання хмарних сервісів для управління проєктами та колективної розробки програмних продуктів.

\section{СПИСОК ВИКОРИСТАНОЇ ЛІТЕРАТУРИ}

1. Власюк А. Підготовка фахівців 3 інформаційних технологій у контексті сучасних вимог / А. Власюк, П. Грицюк // Нова педагогічна думка. - 2013. - № 1 (1). URL: http://nbuv.gov.ua/UJRN/ Npd_2013_1_28 (дата звернення: 02.08.2019).

2. Гладун М. Сучасні онлайн-інструменти інтерактивного навчання як технологія співробітництва / М. Гладун, М. Сабліна // Відкрите освітнє е-середовище сучасного університету. - 2018. - № 4. - C. 33-43. URL: http:// elibrary.kubg.edu.ua/id/eprint/25818/1/M_Gladun_M Sablina OEEMU FITU.pdf (дата звернення: 01.08.2019).

3. Глазунова О. Г. Теоретико-методичні засади проектування та застосування системи електронного навчання майбутніх фахівців 3 інформаційних технологій в університетах аграрного профілю : дис. ... д-ра пед. наук : 13.00.10 / О. Г. Глазунова ; Національний університет біоресурсів і природокористування України. - Київ, 2015.
4. Зубик Л. В. Формування професійних компетентностей майбутніх бакалаврів 3 інформаційних технологій у процесі вивчення фахових дисциплін : дис. ... канд. пед. наук : 13.00 .04 / Л. В. Зубик ; НУВГП. - Рівне, 2016.

5. Концедайло В. В. Наукові підходи до формування професійних компетентностей майбутніх інженерів-програмістів у вітчизняній та зарубіжній літературі / В. В. Концедайло // Інформаційні технології в освіті. - 2017. - № 3 (32). - С. 112-130.

6. Корольчук В. І. Організація міждисциплінарних проектів в підготовці IT-фахівців / В. І. Корольчук ; Національна академія педагогічних наук України ; Інститут інформаційних технологій і засобів навчання. 2018. - C. 99-102.

7. Круглик В. Аналіз змісту та організації підготовки фахівців з програмної інженерії в університетах США / В. Круглик, В. Осадчий, С. Симоненко // Педагогічний дискурс. - 2016. - Вип. 20. - С. 107-114.

8. Осадчий В. В. Анализ проблемы профессиональной подготовки программиста и пути ее решения / В. В. Осадчий, К. П. Осадча // Образовательные технологии и общество. - 2014. - Т. 17. - № 3. C. $362-377$.

9. Проскура С. Л. Підготовка фахівців 3 інформаційних технологій у закладах вищої освіти: стан, проблеми і перспективи / С. Л. Проскура, С. Г. Литвинова // Інформаційні технології в освіті. - 2018. № 2 (35). - С. 72-88.

10. Слюсарчук Ю. Технології проектного навчання під час підготовки ІТ-фахівців / Ю. Слюсарчук // Науковий вісник НЛТУ України. -2015. - Вип. 25 (5).C. 369-374.

11. Татауров В. П. Використання сервісів для організації освітньо-інформаційного середовища студентів ІТ-спеціальностей / В. П. Татауров, К. С. Чевська. - 2018. - С. 120-124.

12. Ellison A. Harnessing the power of Office 365 to provide a social learning environment through a new Student Portal [Electronic resource] / A. Ellison, M. Arora // 19th EUNIS Congress «ICT Role for Next Generation Universities», 2013. URL: https://eunis2013journals.rtu.lv/article/view/eunis.2013.010 (дата звернення: 05.08.2019)

13. Feliciano J. Student Experiences Using GitHub in Software Engineering Courses : A Case Study [Electronic resource] / J. Feliciano, M. Storey, A. Zagalsky // 38th IEEE International Conference on Software Engineering Companion. - 2016. URL: https://alexeyza.com/pdf/ icse16seet.pdf (дата звернення: 04.08.2019).

14. Glazunova O. E-environment based on Microsoft Sharepoint for the organization of group project work of students at higher education institutions [Electronic resource] / O. Glazunova, O. Kuzminska, T. Voloshyna, T. Sayapina, V. Korolchuk // Information Technologies and Learning Tools. - 2017. - Vol. 62. - № 6. P. 98-113. URL: https://journal.iitta.gov.ua/index.php/ itlt/article/view/1837 (дата звернення: 05.08.2019).

Дата надходження до редакиї: 09.08.2019 р. 